\title{
Letter
}

\section{Acute renal failure in critically ill HIV-infected patients}

\author{
José António Lopes ${ }^{1}$, Joana Fernandes ${ }^{2}$, Sofia Jorge ${ }^{1}$, José Neves ${ }^{2}$, Francisco Antunes ${ }^{2}$ \\ and Mateus Martins Prata ${ }^{1}$
}

\begin{abstract}
1'Department of Nephrology and Renal Transplantation, Hospital de Santa Maria, Av. Prof. Egas Moniz, 1649-035 Lisbon, Portugal
${ }^{2}$ Department of Infectious Diseases, Hospital de Santa Maria, Av. Prof. Egas Moniz, 1649-035 Lisbon, Portugal
\end{abstract}

Corresponding author: José António Lopes, jalopes93@hotmail.com

Published: 23 January 2007

This article is online at http://ccforum.com/content/11/1/404

(C) 2007 BioMed Central Ltd
Critical Care 2007, 11:404 (doi:10.1186/cc5141)

The overall mortality was $43.3 \%$, and mortality was higher among ARF patients (30 versus 12 patients; $P<0.0001$ ). The majority of patients (95\%) died within the first month of hospitalization, in the intensive care unit. Patients who did not die, however, had complete renal function recovery. Multivariate regression analysis showed that ARF (odds ratio, $0.27 ; 95 \%$ confidence interval, 0.1-0.67; $P=0.007$ ) and illness severity (Simplified Acute Pathophysiology Score II >50; odds ratio, $0.19 ; 95 \%$ confidence interval, 0.07-0.53; $P=0.002$ ) were independently associated with mortality.

We evaluated retrospectively the incidence of ARF, as well its aetiology, risk factors, therapy and outcome, among HIVinfected patients admitted to the Infectious Diseases Intensive Care Unit of our hospital between January 2002 and June 2006. ARF was defined by means of the Risk Injury Failure Loss End-stage classification [2]. ARF was considered if there was at least a 1.5-fold increase of serum creatinine or a urinary output lower than $0.5 \mathrm{ml} / \mathrm{kg} /$ hour for 6 hours.

Ninety-seven patients (mean age, $42.7 \pm 12.2$ years; 77 male, 69 Caucasian) were evaluated. Forty-six patients $(47.4 \%)$ (mean age, $43.2 \pm 11.1$ years; $P=$ not significant; 39 male, $P=$ not significant; 38 Caucasian, $P=$ not significant) had some degree of renal dysfunction, and did not differ in terms of age, gender, race, type of HIV, CD4+ lymphocyte count, stage of HIV infection, Highly Active Antiretroviral Therapy, comorbidity, and severity of illness. Sepsis ( $n=39,84 \%)$ was the most common aetiology. Seven patients (15.2\%) received renal replacement therapy (continuous venovenous haemodiafiltration). By multivariate regression analysis, age $>60$ years (odds ratio, 5.32; 95\% confidence interval, 1.23-23; $P=0.025$ ), hepatitis C (odds ratio, $3.42 ; 95 \%$ confidence interval, 1.08-10.85; $P=0.037$ ), as well as severity of illness (Simplified Acute Pathophysiology Score II $>50$; odds ratio, $0.26 ; 95 \%$ confidence interval, $0.1-0.7$; $P=0.008$ ) emerged as independent predictors of ARF.
In summary, ARF is common among critically ill HIV-infected patients and increases mortality. Sepsis is the most common associated aetiology, and age, hepatitis C, and severity of illness are independent predictors of ARF in this setting.

\section{Authors' contributions}

JAL, JF, and SJ made substantial contributions to conception and design, acquisition of data, and analysis and interpretation of data. JAL, JN, FA, and MMP were involved in drafting the manuscript or revising it critically for important intellectual content. All authors have given final approval of the version to be published.

\section{Competing interests}

The author(s) declare that they have no competing interests.

\section{References}

1. Wyatt CM, Arons RR, Klotman PE, Klotman ME: Acute renal failure in hospitalized patients with HIV: risk factors and impact on in-hospital mortality. AIDS 2006, 20:561-565.

2. Bellomo R, Ronco C, Kellum JA, Mehta, RL, Palevsky P, and the ADQI Workgroup: Acute renal failure - definition, outcome measures, animal models, fluid therapy and information technology needs: the Second International Consensus Conference of the Acute Dialysis Quality Initiative (ADOI) Group. Crit Care 2004; 8:R204-R212. 